\title{
PROGNOZOWANIE KRZYWEJ OSIADANIA PALA WIERCONEGO Z INIEKCJĄ CIŚNIENIOWĄ POD PODSTAWĄ
}

\author{
Adam Krasiński ${ }^{\bowtie}$ \\ Wydział Inżynierii Lądowej i Środowiska, Politechnika Gdańska, Gdańsk
}

\begin{abstract}
STRESZCZENIE
Podczas XVII Krajowej Konferencji MGiIG zorganizowanej w 2015 roku w Łodzi autor wygłosił referat oraz opublikował artykuł pt.: „Ocena działania iniekcji pod podstawą pala wierconego za pomocą badania statycznego nośności z pomiarem rozkładu siły w trzonie pala". W artykule przeanalizowano mechanizm działania iniekcji i wykazano, że w głównej mierze uaktywnia ona zwiększone opory gruntu wzdłuż pobocznicy pala, poprawiając w ten sposób sztywność osiową pala w gruncie. Analizę poparto wynikami badań pali rzeczywistych, oprzyrządowanych pomiarowo. Na bazie wyników wyżej opisanych analiz i rozważań w niniejszym artykule zaproponowano metodę obliczeniową prognozowania krzywej osiadania pala wierconego z iniekcją ciśnieniową pod podstawą. W schemacie obliczeniowym pala zastosowano charakterystyki współpracy pala z gruntem opisane funkcjami transferowymi. Procedura obliczeniowa przebiega kilkuetapowo i może być zrealizowana w standardowym arkuszu kalkulacyjnym. W artykule przedstawiono dwa przykłady obliczeniowe, w których zaprognozowano krzywą osiadania pala z iniekcją i porównawczo tego samego pala bez iniekcji pod podstawą. Zaproponowana metoda obliczeniowa dobrze odwzorowuje mechanizm i efekt działania iniekcji. Przy swojej przejrzystości i prostocie może znaleźć zastosowanie praktyczne w efektywnym projektowaniu fundamentów palowych.
\end{abstract}

Słowa kluczowe: pal, pal wiercony, iniekcja pod podstawą pala, krzywa osiadania pala, obliczenia pali

\section{WSTĘP}

Mechanizm działania iniekcji ciśnieniowej pod podstawą pala wierconego został szczegółowo opisany i wyjaśniony we wcześniejszej pracy autora (Krasiński, 2015a) oraz przedstawiony schematycznie na rysunku 1. Zadaniem takiej iniekcji jest wprowadzenie wstępnej siły ściskającej między podstawą pala a gruntem, która to siła uaktywnia ujemne (skierowane w dół) opory tarcia gruntu wzdłuż pobocznicy pala oraz powoduje wstępne naprężenie i skonsolidowanie gruntu pod jego podstawą. W gruntach niespoistych może dodatkowo dochodzić do cementacji pewnej objętości gruntu i zwiększenia efektywnej powierzchni podstawy pala. Sporo informacji na temat technologii wykony- wania i efektywności stosowania iniekcji pod podstawą pali wierconych wielkośrednicowych można znaleźć między innymi w pracach Pinkowskiego i Gwizdały (2006), Gwizdały i Pinkowskiego (2007), Gwizdały (2011, 2013), Gwizdały i Krasińskiego (2015).

Na rysunku 1 wartości oporów i przemieszczeń, odpowiadające momentowi zadziałania iniekcji, oznaczone są na wykresach punktami A, a wartości ustabilizowane (trwałe, po uwzględnieniu strat) - punktami B. Rzeczywiste wartości strat są trudne do pomierzenia, ale można je szacować na poziomie 30-50\%. Punktami A' i B' oznaczono przemieszczenia (osiadania) gruntu pod podstawą pala wywołane iniekcją ciśnieniową, które w warunkach rzeczywistych są również trudne do pomierzenia. Podczas przenoszenia

\footnotetext{
凶akra@pg.edu.pl
} 


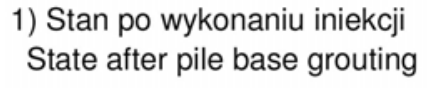
2) Próbne obciążenie pala Static load test

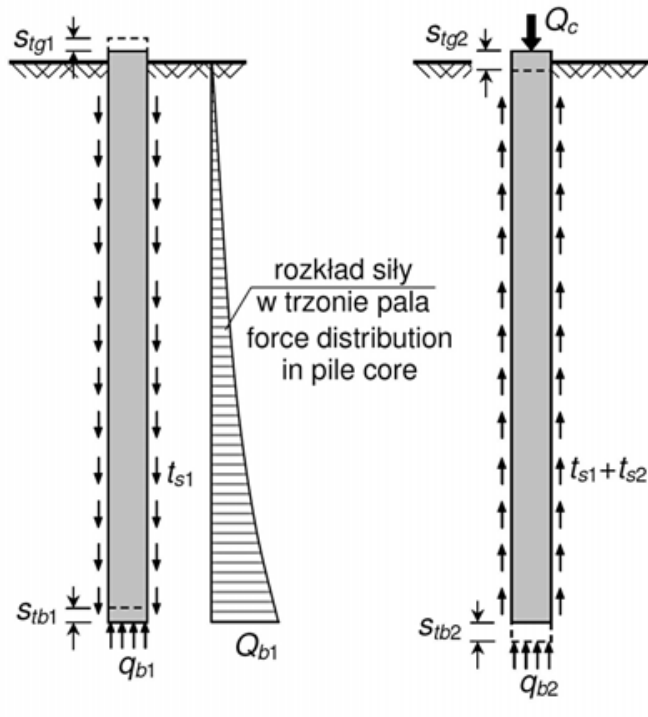

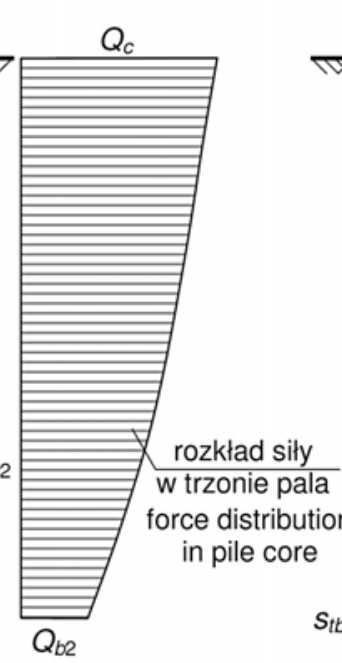

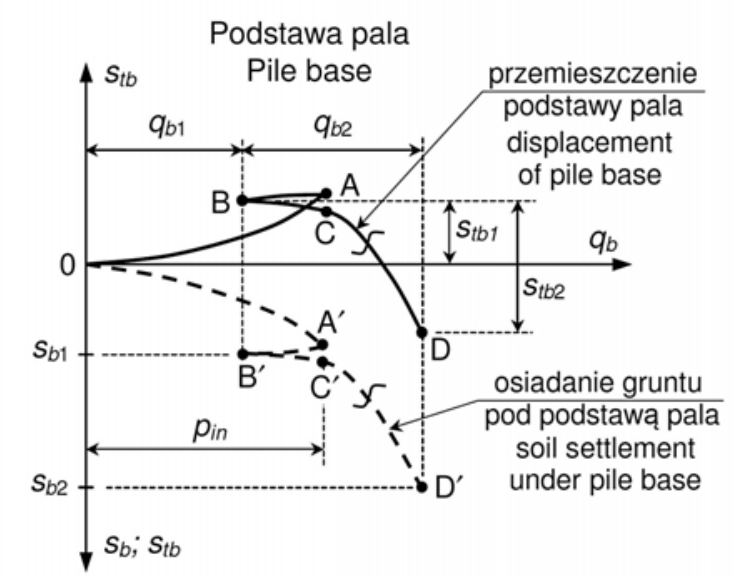

3) Stan sumaryczny
Summarising state

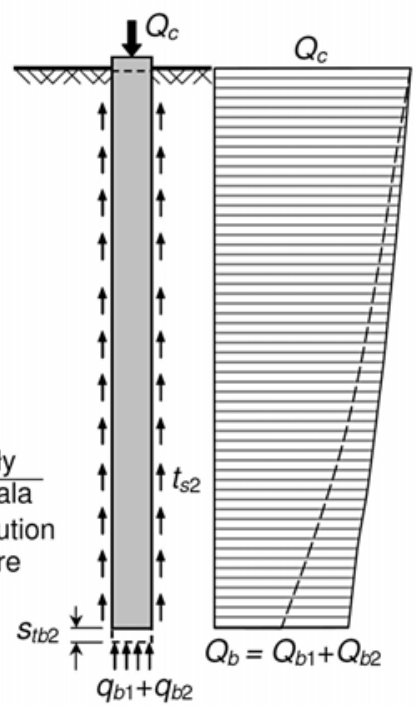

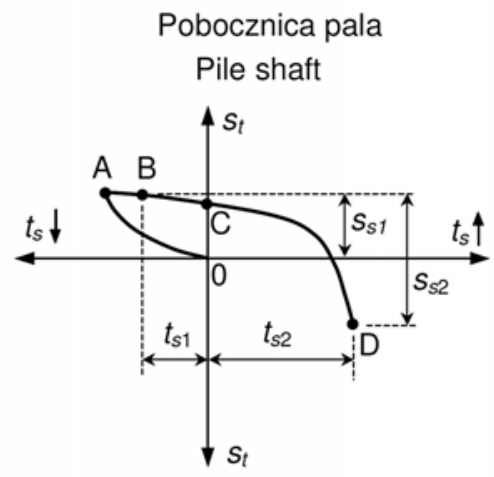

Rys. 1. Schemat ideowy działania iniekcji ciśnieniowej pod podstawą pala (Krasiński, 2015a)

Fig. 1. Schematic work idea of the pressure grouting under the pile base (Krasiński, 2015a)

przez pal obciążeń zewnętrznych (np. podczas próbnego obciążenia) obserwuje się wyraźnie zmniejszone osiadania początkowe pala z iniekcją podstawy w stosunku do pala bez iniekcji. Z schematu ideowego na rysunku 1 wynika, że zmniejszenie tego osiadania jest przede wszystkim efektem zwiększonej możliwości przenoszenia obciążeń przez pobocznicę pala. Opór podstawy pala osiąga obniżoną wartość $\left(Q_{b 2}\right)$, ale trzeba zaznaczyć, że dokłada się on do już istniejącej siły, wygenerowanej przez iniekcję $\left(Q_{b 1}\right)$.

\section{AUTORSKA METODA PROGNOZOWANIA KRZYWEJ OSIADANIA PALA Z UWZGLĘDNIENIEM INIEKCJI POD PODSTAWA}

Po przeanalizowaniu opisanego wcześniej mechanizmu działania iniekcji ciśnieniowej pod podstawą pala wierconego autor uznał, że mechanizm ten można stosunkowo prosto odwzorować metodą funkcji transferowych (inaczej transformacyjnych). Metoda ta służy do prognozowania krzywej osiadania pala 
pojedynczego. Została opracowana i szczegółowo opisana między innymi przez Gwizdałę $(1996,2011)$ oraz przedstawiona w wielu innych publikacjach tego samego autora (Gwizdała i Krasiński, 2016). Schemat obliczeniowy pala do metody przedstawiono na rysunku 2.

Funkcje transferowe najczęściej przyjmuje się o postaciach c i e pokazanych na rysunku 2 i wyraża zależnościami potęgowymi:

$$
t_{s}=t_{s ; \max }\left(\frac{s_{s}}{z_{v}}\right)^{\alpha} \quad \text { dla } t_{s} \leq t_{s ; \max }
$$

oraz

$$
q_{b}=q_{b ; f}\left(\frac{s_{b}}{z_{f}}\right)^{\beta} \quad \text { dla } q_{b} \leq q_{b ; f}
$$

gdzie:

$\alpha$ - wykładnik funkcji $t_{s}-z$, który przyjmuje się z przedziału 0,3 do 0,5 ;

$z_{v}$ - przemieszczenie pobocznicy pala, przy którym mobilizuje się maksymalny opór tarcia gruntu $t_{s ; \max } ; z_{v}$ przyjmowane jest najczęściej o wartości z przedziału 5-10 $\mathrm{mm}$ lub równej $0,01 D$ ( $D$ - średnica pala);

$\beta$ - wykładnik funkcji $q_{b}$-z, którego wartość przyjmuje się najczęściej od 0,25 do 0,6;

$z_{f}$ - przemieszczenie podstawy pala, przy którym mobilizuje się graniczny opór gruntu $q_{b ; f}$ pod podstawą; $z_{f}$ przyjmowane jest najczęściej o wartości z przedziału $(0,05-0,1) D$.

Wartości oporów granicznych $t_{s, \text { max }}$ i $q_{b ; f}$ można określać np. metodami wykorzystywanymi do obliczania nośności pali.

Funkcje transferowe zaproponowane przez Gwizdałę (1996, 2011) odnoszą się do obciążeń pierwotnych pala. Do procedury prognozowania krzywej osiadania pala $\mathrm{z}$ iniekcją podstawy potrzebne są także funkcje do odciążeń i obciążeń wtórnych. Wykorzystując własne doświadczenia oraz znajomość zachowania się gruntów autor, po przeprowadzeniu testów próbnych, zaproponował następujące modyfikacje funkcji transferowych do odciążeń i obciążeń wtórnych: a)

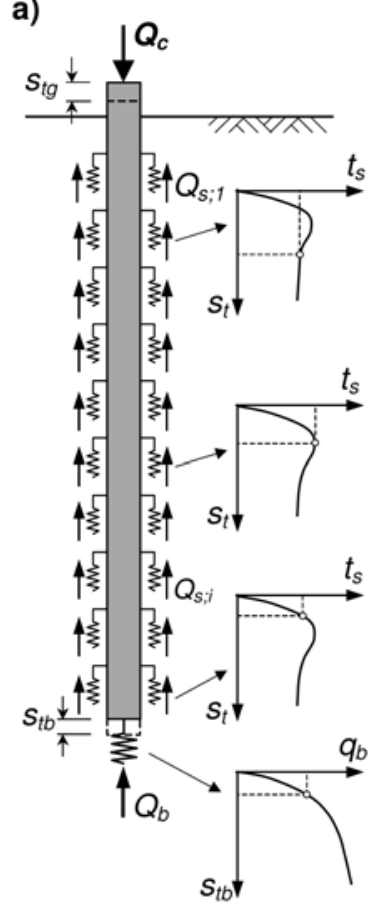

Rodzaje funkcji transferowych Types of load-transfer functions b)

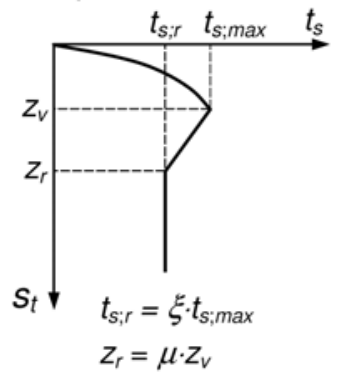

c)

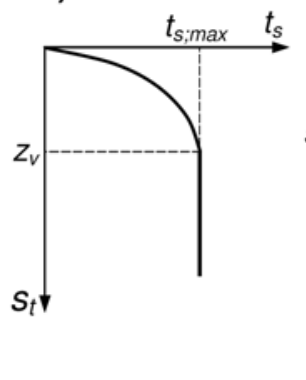

d)

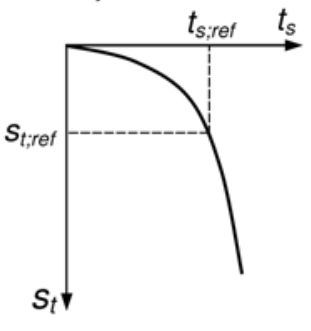

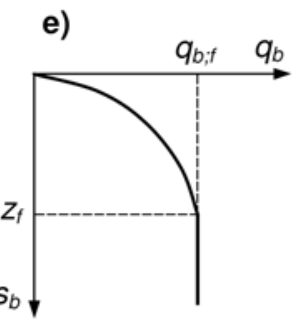

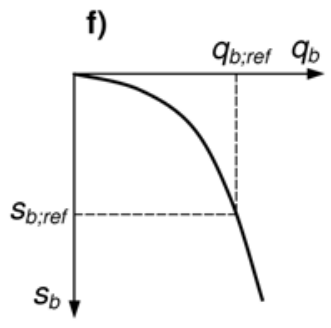

Rys. 2. Schemat współpracy pala $\mathrm{z}$ gruntem $\mathrm{w}$ metodzie funkcji transferowych

Fig. 2. Soil-pile interaction scheme in the load-transfer functions method 
- do odciążeń:

$$
\begin{aligned}
& \Delta t_{s}=-2 \cdot t_{s ; \max }\left(\frac{\Delta s_{s}}{0,5 \cdot z_{v}}\right)^{\alpha} \\
& \operatorname{przy} t_{s} \leq t_{s ; 0} \text { dla } t_{s}, t_{s ; 0}>0 \\
& \text { oraz } t_{s} \geq t_{s ; 0} \text { dla } t_{s}, t_{s ; 0}<0 \\
& \Delta q_{b}=-2 \cdot q_{b ; f}\left(\frac{\Delta s_{b}}{0,5 \cdot z_{f}}\right)^{\beta} \quad \operatorname{przy} q_{b} \leq q_{b ; 0}
\end{aligned}
$$

- do obciążeń wtórnych:

$$
\begin{aligned}
& \Delta t_{s}=1,5 \cdot t_{s ; \max }\left(\frac{\Delta s_{s}}{z_{v}}\right)^{\alpha} \\
& \operatorname{przy} t_{s} \leq t_{s ; 0} \text { dla } t_{s}, t_{s ; 0}>0 \\
& \operatorname{oraz} t_{s} \geq t_{s ; 0} \text { dla } t_{s}, t_{s ; 0}<0 \\
& \Delta q_{b}=1,5 \cdot q_{b ; f}\left(\frac{\Delta s_{b}}{z_{f}}\right)^{\beta} \quad \operatorname{przy} q_{b} \leq q_{b ; 0}
\end{aligned}
$$

Parametry $t_{s ; \max }, z_{v}, \alpha, q_{b ; f}, z_{f}$ oraz $\beta$ należy przyjmować takie same jak w funkcjach transferowych do obciążeń pierwotnych, określonych wzorami (1) i (2). Wielkości $t_{s ; 0}$ i $q_{b ; 0}$ oznaczają wartości oporów gruntu w końcowej fazie obciążenia pierwotnego, tuż przed odciążeniem. Znak minus we wzorach (3) i (4) oznacza, że kierunek odciążenia jest przeciwny do obciążenia pierwotnego.

Pokazane na rysunku 3 wyniki testów z zaproponowanymi funkcjami transferowymi do odciążeń i obciążeń wtórnych ogólnie przedstawiają się korzystnie i realistycznie.

Procedura obliczeniowa wyznaczania krzywej osiadania pala $\mathrm{z}$ iniekcją pod podstawą składa się z pięciu zasadniczych etapów.

W etapie I odwzorowuje się reakcję gruntu w fazie wykonywania iniekcji ciśnieniowej pod podstawą pala. Wykorzystuje się w nim funkcje transferowe do obciążeń pierwotnych.

W etapie II odwzorowuje się stan w okresie od wykonania iniekcji do próbnego obciążenia pala. W okresie tym następuje redukcja reakcji gruntu $\mathrm{w}$ wyniku strat w ciśnieniu iniekcji oraz z powodu zjawisk reologicznych $\mathrm{w}$ gruncie. $\mathrm{W}$ rozpatrywanym etapie wykorzystuje się funkcje transferowe do odciążeń. a) $t_{s}[\mathrm{kPa}]$

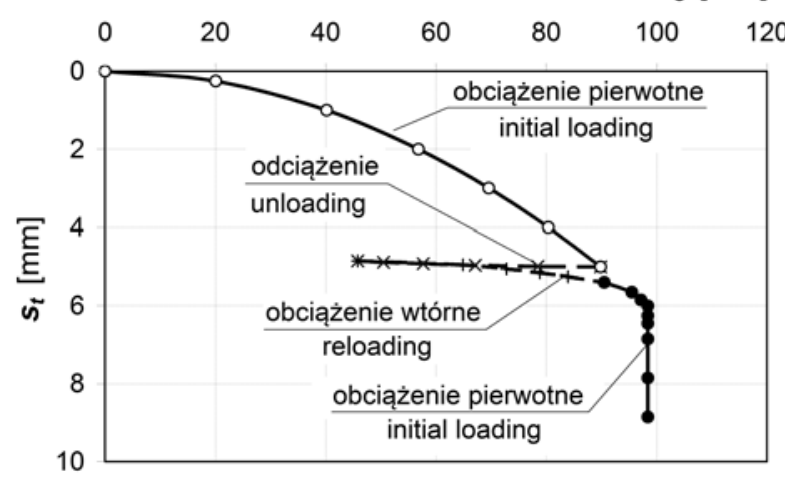

b)

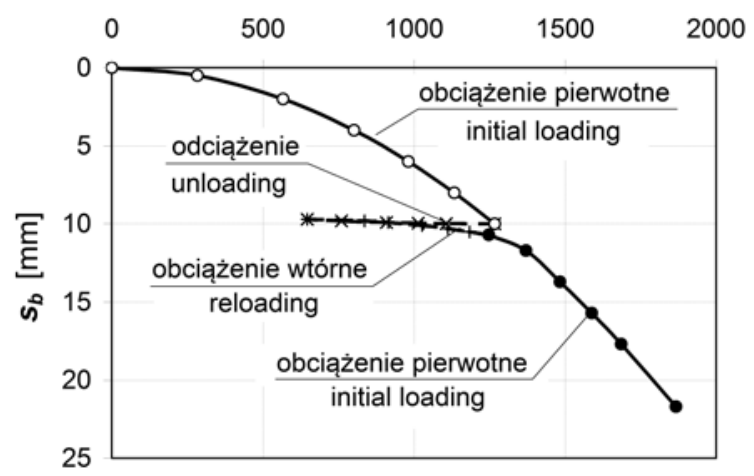

Rys. 3. Wykresy przykładowych testów funkcji transferowych do odciążeń i obciążeń wtórnych

Fig. 3. Graphs of exemplary tests of transfer functions for unloading and reloading

W etapie III odwzorowuje się początkową fazę próbnego obciążenia pala do momentu, w którym stan naprężenia $\mathrm{w}$ gruncie pod podstawą pala wraca do poziomu z końca etapu I. W etapie tym wykorzystuje się funkcje transferowe do odciążeń w odniesieniu do oporów gruntu wzdłuż pobocznicy, natomiast funkcje transferowe do obciążeń wtórnych w odniesieniu do oporów gruntu pod podstawą pala.

W etapie IV odwzorowuje się pozostałe fazy próbnego obciążenia pala. Wykorzystuje się w nim funkcje transferowe do obciążeń pierwotnych zarówno do oporów gruntu wzdłuż pobocznicy, jak i pod podstawą pala. Należy przy tym pamiętać, że do oporów gruntu wzdłuż pobocznicy przyjmuje się przyrosty osiadań $\left(s_{t, I V}=\Delta s_{t ; I V}\right)$, a do oporów gruntu pod podstawą pala - wartości osiadań zsumowane ze wszystkich etapów $\left(s_{b ; I V}=s_{b ; I}+\Delta s_{b ; I I}+\Delta s_{b ; I I I}+\Delta s_{b ; I V}\right)$. 
W etapie V tworzy się składowe i całkowitą krzywych osiadania, $Q_{s}(s), Q_{b}(s)$ i $Q_{c}(s)$. Otrzymuje się je z sumowania oddziaływań i przemieszczeń (osiadań) $\mathrm{z}$ etapów III i IV. Jako stan początkowy w etapie $\mathrm{V}$ $\left(s=0, Q_{s}=0, Q_{b}=0\right)$ przyjmuje się stan z początku etapu III. Przebieg procedury obliczeniowej można dokładniej prześledzić na przykładach obliczeniowych.

\section{PRZYKŁADY OBLICZENIOWE}

Poniżej przedstawiono przykłady obliczeniowe dotyczące dwóch pali wierconych wielkośrednicowych o identycznych parametrach geometrycznych (średnica $D=1,2 \mathrm{~m}$ i długość $L=16,0 \mathrm{~m}$ ), ale zagłębionych w różnych warunkach gruntowych (rys. 4 i 11). Przykłady mają charakter akademicki i nie odnoszą się do przypadków pali rzeczywistych.

Wartości oporów granicznych $t_{s, \text { max }}$ i $q_{b ; f}$ określono na podstawie propozycji polskiej normy PN-B-02482:1983 z uwzględnieniem współczynników technologicznych $S_{s}$ i $S_{p}$ oraz interpolacji względem głębokości. Zastosowano też wskazówkę Sobali (2012, 2014) zwiększenia o $25 \%$ normowych wartości oporów $t_{s}$ i $q_{b} \mathrm{~W}$ celu zbliżenia ich do wartości granicz- nych według standardów EC7 (PN-EN 1997-1:2008. Eurokod 7. Projektowanie geotechniczne), w których pełna mobilizacja oporów granicznych następuje przy osiadaniach pala równych $0,1 D$. W obliczeniach obu przykładów pominięto skrócenie własne trzonu pala, ze względu na bardzo dużą jego sztywność osiową, dzięki czemu obliczenia można było wykonać bez iteracji.

\section{Przykład obliczeniowy 1}

Przykład dotyczy pala zagłębionego w podłożu z gruntów mineralnych, z których warstwa o obniżonych parametrach mechanicznych zbudowana jest nieskonsolidowanego pyłu ilastego (glina pylasta) w stanie plastycznym. Dane geometryczne i materiałowe do przykładu oraz przyjęty schemat obliczeniowy pala z parametrami funkcji transferowych przedstawiono na rysunku 4.

Na początku wyznaczono krzywe osiadania pala bez iniekcji podstawy, które obliczono standardową, jednoetapowa procedura funkcji transferowych do obciążeń pierwotnych. Krzywe te przedstawiono je na rysunku 5.

Następnie przeprowadzono obliczenia etapów I i II, których wyniki przedstawiono na rysunku 6 . W etapie I zadano takie ciśnienie iniekcji pod podstawa pala, które spowodowało uniesienie jego trzonu o wartość
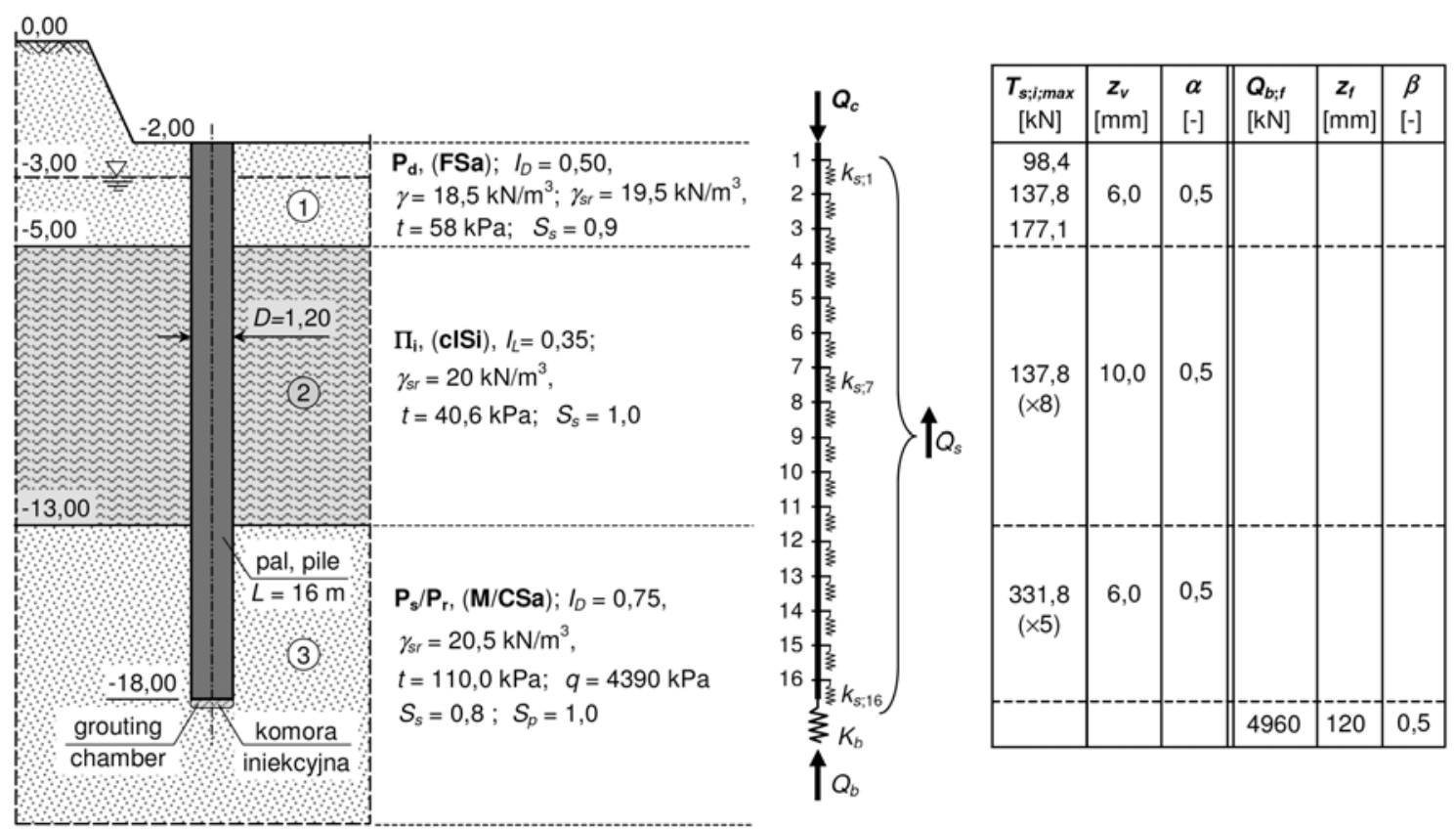

Rys. 4. Dane do przykładu obliczeniowego 1

Fig. 4. Data for the calculation of example 1 


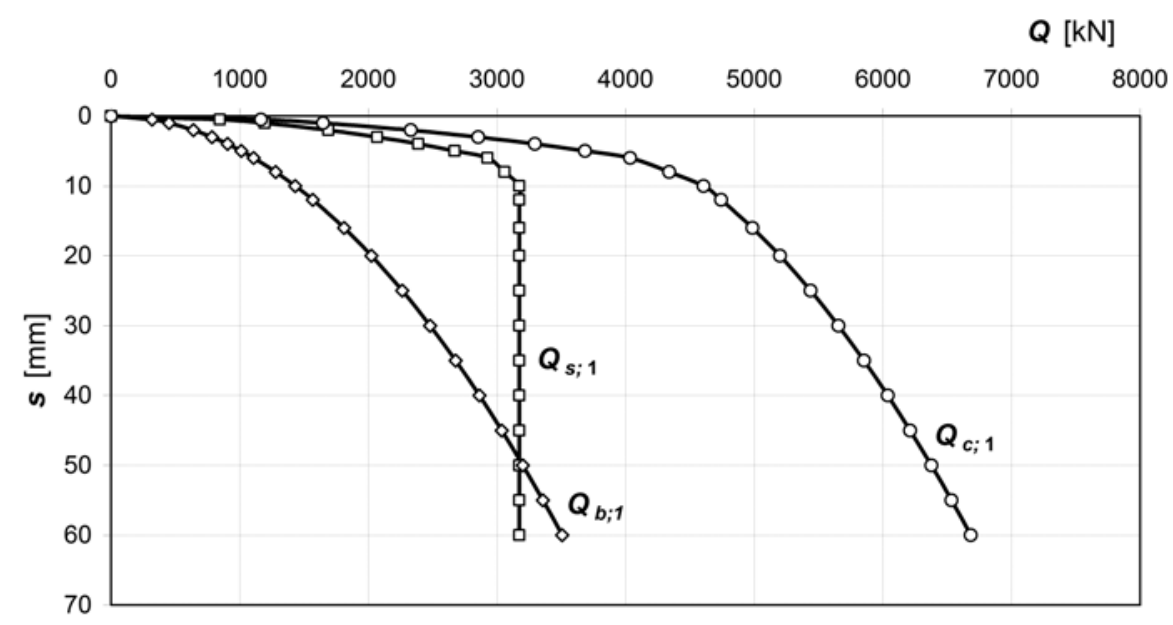

Rys. 5. Przykład 1 - krzywe osiadania pala bez iniekcji podstawy, wyznaczone z obliczeń

Fig. 5. Calculation example 1 - load-settlement characteristics for pile without grouting under the base

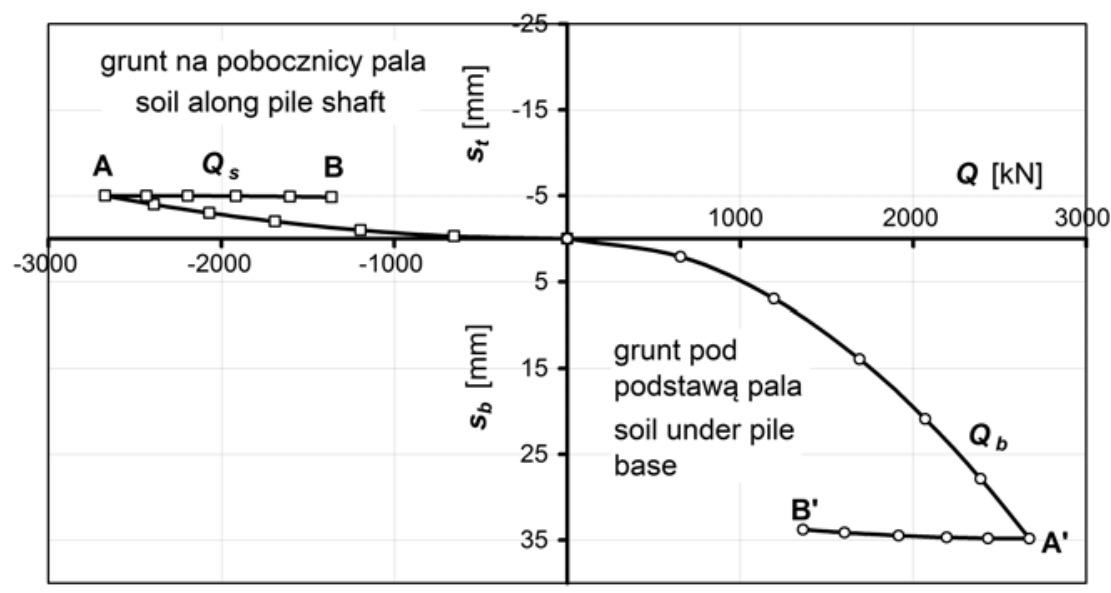

Rys. 6. Przykład 1 - wykresy oporów gruntu, otrzymane $z$ etapów obliczeniowych I i II

Fig. 6. Calculation example 1 - soil resistance graphs obtained from the calculation phases I and II

$s_{t}=5 \mathrm{~mm}$. Wymagane ciśnienie wyniosło $p_{i n: 1}=2,36$ MPa i wywołało wstępną siłę sprężającą trzon pala i grunt pod jego podstawą o wartości $Q_{i n: 1}=2670 \mathrm{kN}$ (punkty A i A' na rys. 6). Siła ta spowodowała osiadania gruntu pod podstawą pala o wartości około $s_{b}=35 \mathrm{~mm}$ (punkt A'). W etapie II założono straty w sile sprężającej na poziomie $50 \%$, w wyniku czego wartość tej siły spadła do $Q_{b: 1} \approx 1360 \mathrm{kN}$ (punkty B i B' na rys. 6).

Wyniki dalszych obliczeń z uwzględnieniem kolejnych etapów III i IV przedstawiono na rysunku 7 (punkty C, C' oraz D, D').
Wyniki obliczeń etapu $\mathrm{V}$, w którym dokonano zestawienia przemieszczeń $s_{t}$ i $s_{b}$ oraz zsumowania sił $Q_{s}$ i $Q_{b}$, przyjmując za stan początkowy punkty B i B' na rysunku 7 (wartości $Q_{s}, Q_{b}, s_{t}$ i $s_{b}$ przyjęto w tych punktach jako zerowe). Poprawność sumowania sił $Q_{s}$ i $Q_{b}$ wymagała zastosowania zgodności przyrostów przemieszczeń $s_{t}$ i $s_{b}$. Uzyskane krzywe pokazano na rysunku 8 .

Zestawienie porównawcze krzywych osiadania pala bez iniekcji i pala z iniekcją podstawy przedstawiono na rysunkach 9 i 10. Daje się zauważyć wyraźny efekt 


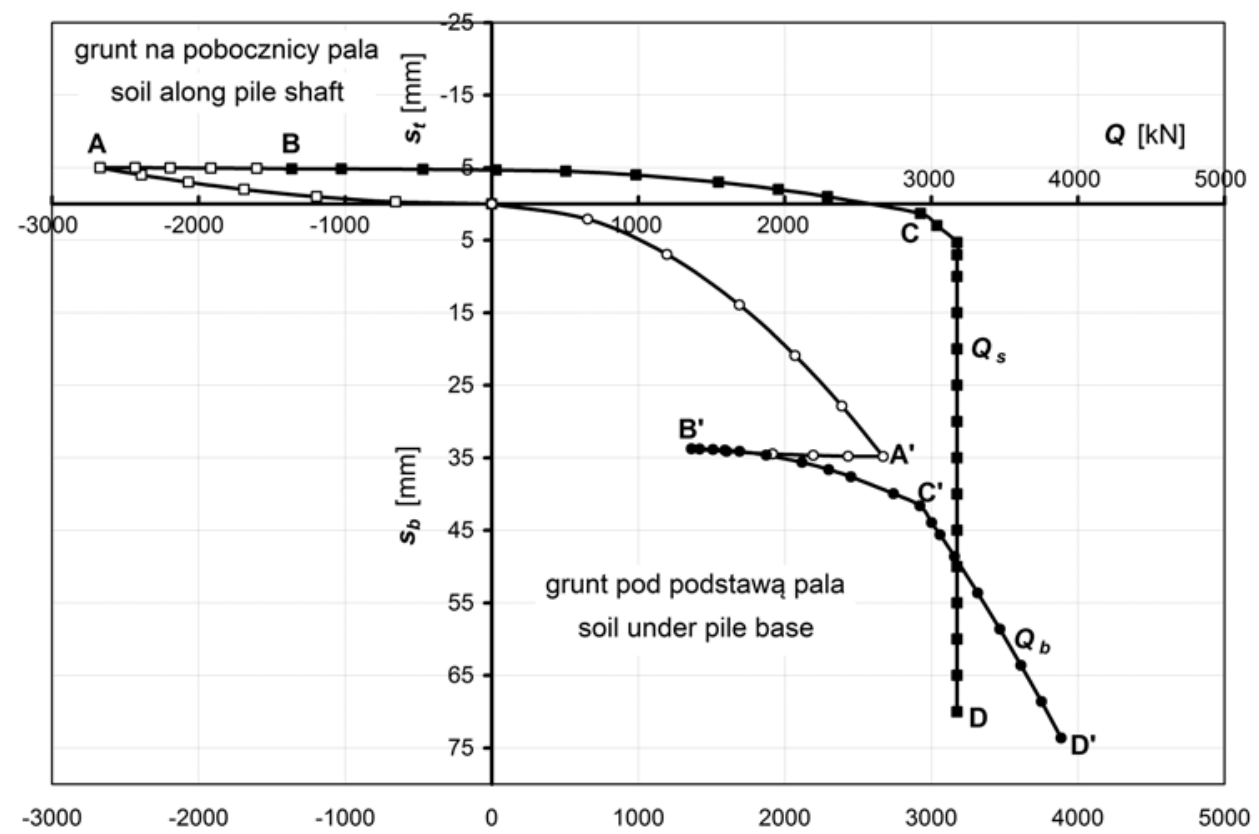

Rys. 7. Przykład 1 - wykresy oporów gruntu, otrzymane $\mathrm{z}$ etapów obliczeniowych I do IV

Fig. 7. Calculation example 1 - soil resistance graphs obtained from the calculation phases I to IV

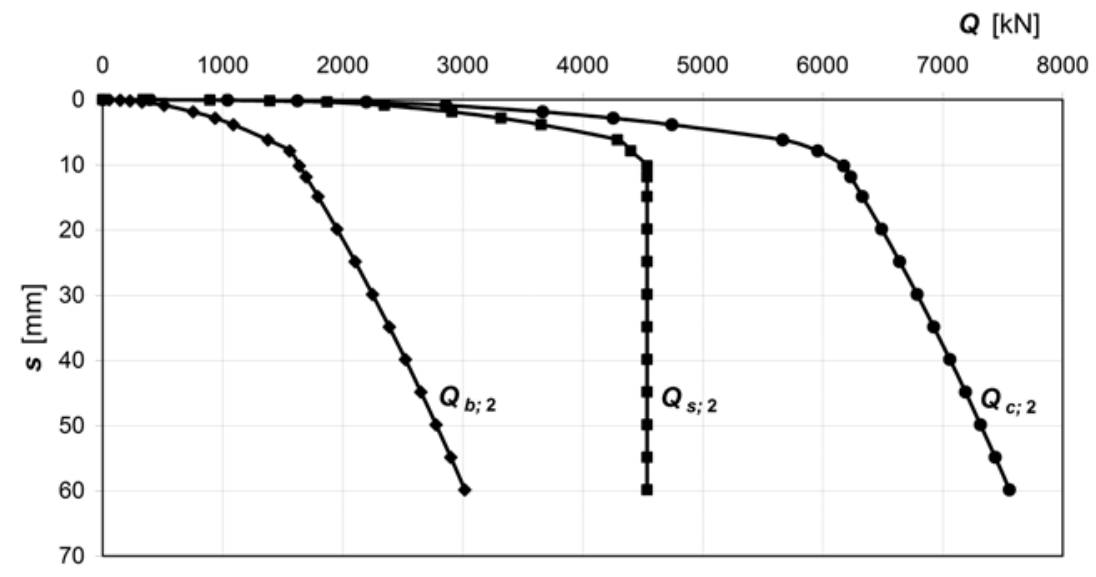

Rys. 8. Przykład 1 - obliczone krzywe osiadania pala z iniekcją podstawy

Fig. 8. Calculation example 1 - load-settlement characteristics for pile with grouting under the base

zastosowania iniekcji ciśnieniowej pod podstawą pala objawiający się zwiększoną sztywnością osiową pala w zakresie obciążeń projektowych oraz przesunięcia do przodu punktu zagięcia na wykresie $Q-S$.

Generalnie uważa się, że gdy iniekcja ciśnieniowa nie zwiększa powierzchni podstawy pala, to nie powoduje ona zwiększenia nośności granicznej pala, a jedynie zwiększenie jego sztywności w gruncie w początkowym zakresie obciążeń. W przedstawionych obliczeniach przyjęto założenie, że iniekcja nie spowoduje zwiększenia powierzchni podstawy pala. Założenie takie jest po stronie bezpiecznej. Wynik przedstawiony na rysunku 11 wskazuje, że faktycznie wzrosła jedynie sztywność pala, a nie wzrosła 


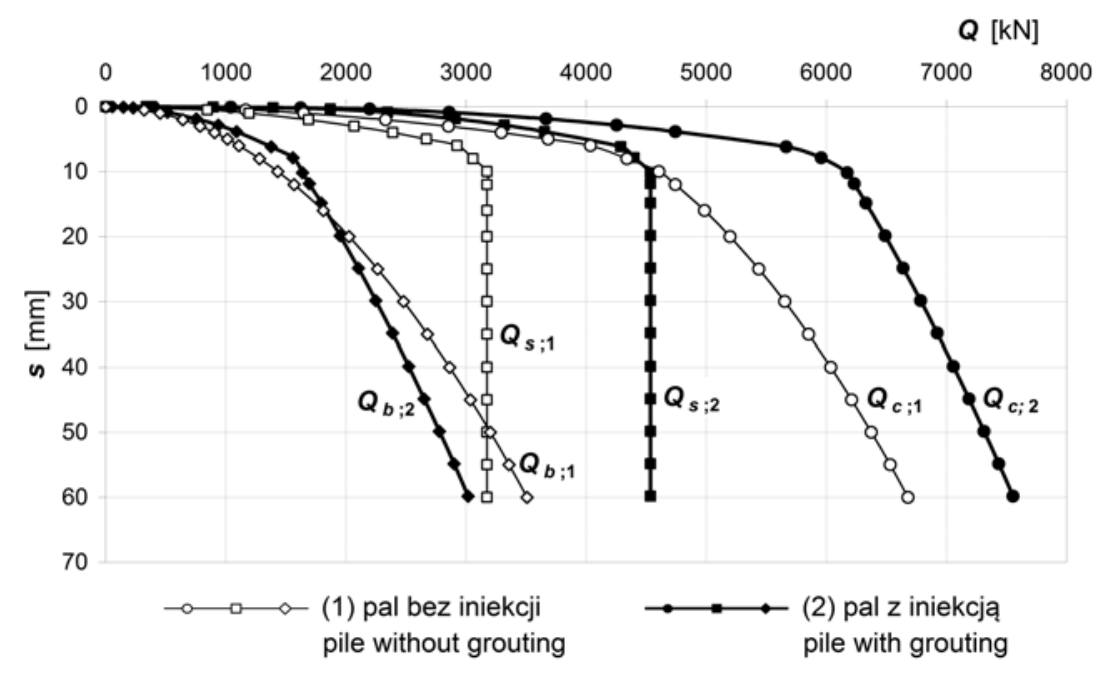

Rys. 9. Przykład 1 - porównanie krzywych osiadania pala bez iniekcji i pala z iniekcją podstawy

Fig. 9. Calculation example 1 - comparison of load-settlement characteristics for pile without grouting and pile with grouting under the base

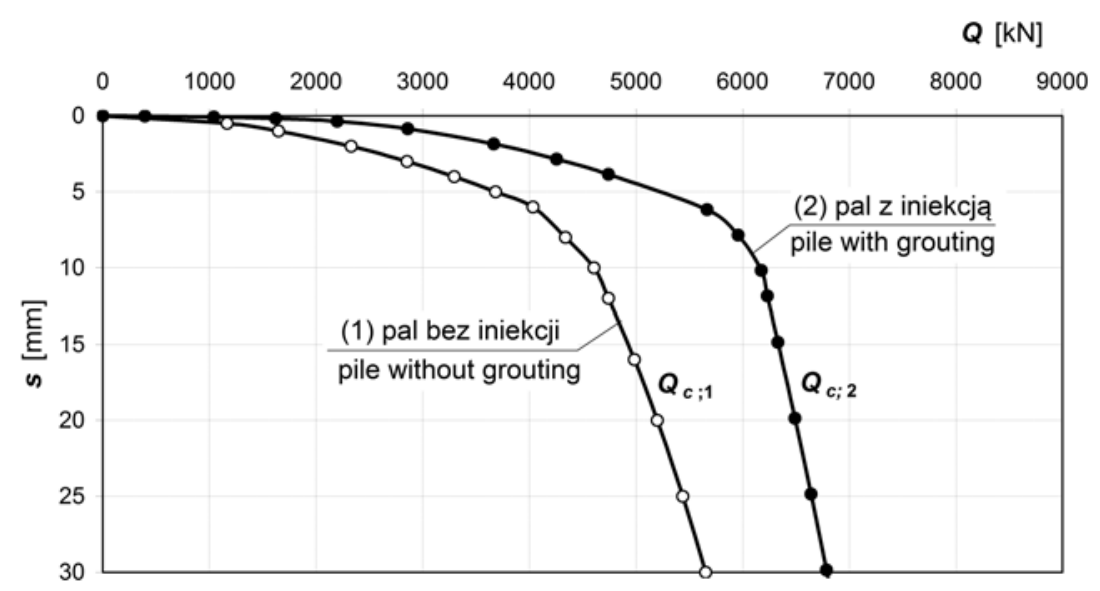

Rys. 10. Przykład 1 - powiększenie krzywych z rysunku 9 dla obciążeń całkowitych $\left(Q_{c}\right)$

Fig. 10. Calculation example 1 - enlarging of curves from Figure 9 for total loads $\left(Q_{c}\right)$

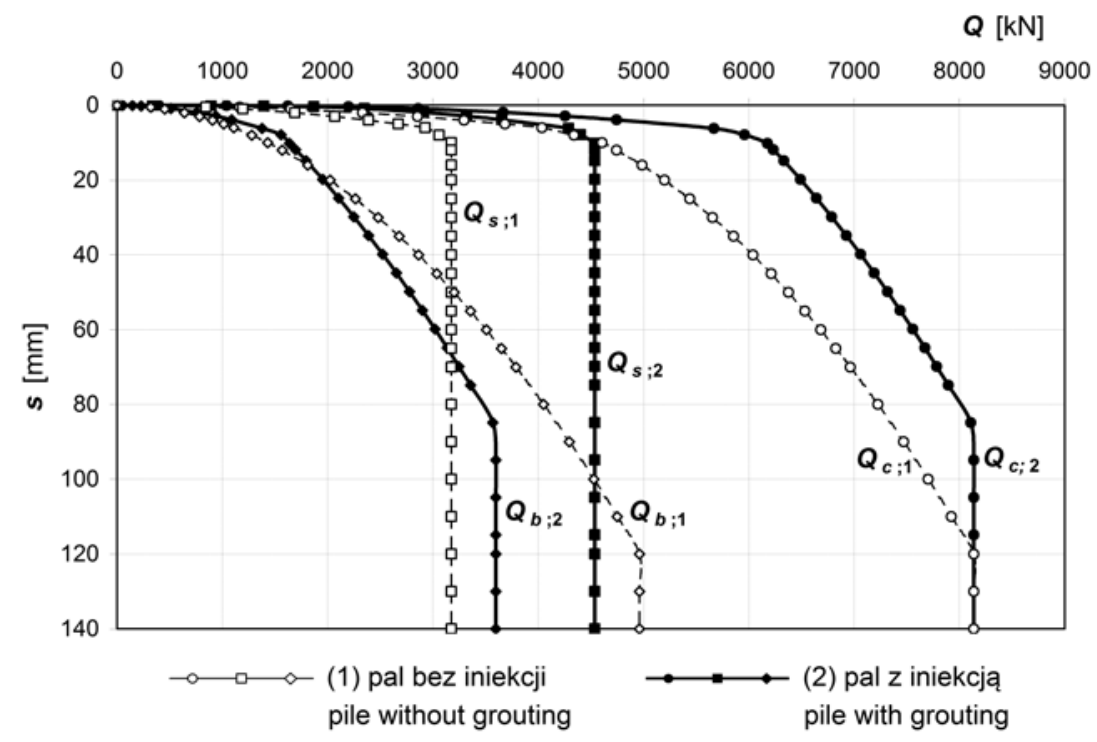

Rys. 11. Przykład 1 - charakterystyki $Q-s$ pali przedłużone do przemieszczeń granicznych

Fig. 11. Calculation example $1-Q-S$ characteristics of piles extended to ultimate values 
nośność graniczna - krzywe $Q_{c}(s)$ obu pali, bez iniekcji i z iniekcją, zbiegają się w tym samym punkcie. Trzeba jednak zaznaczyć, że uzyskany wynik jest częściowo efektem założenia w metodzie funkcji transferowych, że po przekroczeniu przemieszczeń granicznych $z_{v} \mathrm{i} z_{f}$ opory gruntu $t_{s} \mathrm{i} q_{b}$ przestają przyrastać.

\section{Przykład obliczeniowy 2}

Przykład 2 dotyczy pala zagłębionego w podłożu z warstwą słabonośną zbudowaną z namułu organicznego w stanie na pograniczu plastycznego i miękkoplastycznego. Dane do obliczeń przedstawiono na rysunku 12.

Przy wyznaczaniu charakterystyk pala bez iniekcji podstawy przyjęto, że górne dwie warstwy nie przenoszą obciążeń ( $t=0$ - stan długoterminowy). W przypadku pala $\mathrm{z}$ iniekcją podstawy założono, że warstwy te będa przenosić obciążenia jedynie w fazach krótkoterminowych, tzn. w etapach I i II. Dodatkowo założono, że w etapie II nastapi całkowita redukcja do zera oporów w obu wymienionych warstwach. Wartość maksymalną oporu $t$ dla namułu przyjęto według polskiej normy PN-B-02482:1983 jak dla tarcia negatywnego $(t=10 \mathrm{kPa})$.
Cały proces obliczeniowy został przeprowadzony w taki sam sposób, jak w przykładzie 1 . W etapie I, do uniesienia trzonu pala o wartość $s_{t}=5 \mathrm{~mm}$ konieczne było zadanie ciśnienia iniekcji o wartości $p_{i n ; 2}=1,85 \mathrm{MPa}$, co wywołało wstępną siłę sprężająca trzon pala i grunt pod jego podstawą o wartości $Q_{\text {in }: 2}=2090 \mathrm{kN}$ (punkty A i A' na rys. 13) oraz osiadania gruntu pod podstawą pala o wartości około $s_{b}=35 \mathrm{~mm}$ (punkt A'). Podobnie jak wyżej, w etapie II założono stratę $50 \% \mathrm{w}$ oporach dolnej warstwy nośnej piasku średniego i grubego, a stratę $100 \%$ w oporach na pobocznicy w warstwie namułu oraz $\mathrm{w}$ górnej warstwie piasku drobnego, o czym wspomniano już wcześniej. W wyniku strat wartość siły sprężającej spadła do $Q_{b ; 1} \approx 970 \mathrm{kN}$ (punkty B i B' na rys. 13). $\mathrm{Na}$ rysunku 13 pokazano również wyniki dalszych obliczeń z uwzględnieniem kolejnych etapów III i IV (punkty C, C' oraz D, D').

Krzywe osiadania $Q-S$, stanowiace wynik obliczeń końcowego etapu $\mathrm{V}$, wraz $\mathrm{z}$ porównaniem $\mathrm{z}$ takimi samymi krzywymi dla pala bez iniekcji podstawy, przedstawiono na rysunku 14 , a na rysunku 15 , podobnie jak w przykładzie 1, pokazano powiększone, początkowe odcinki krzywych dla oporów całkowitych $\left(Q_{c}\right)$.
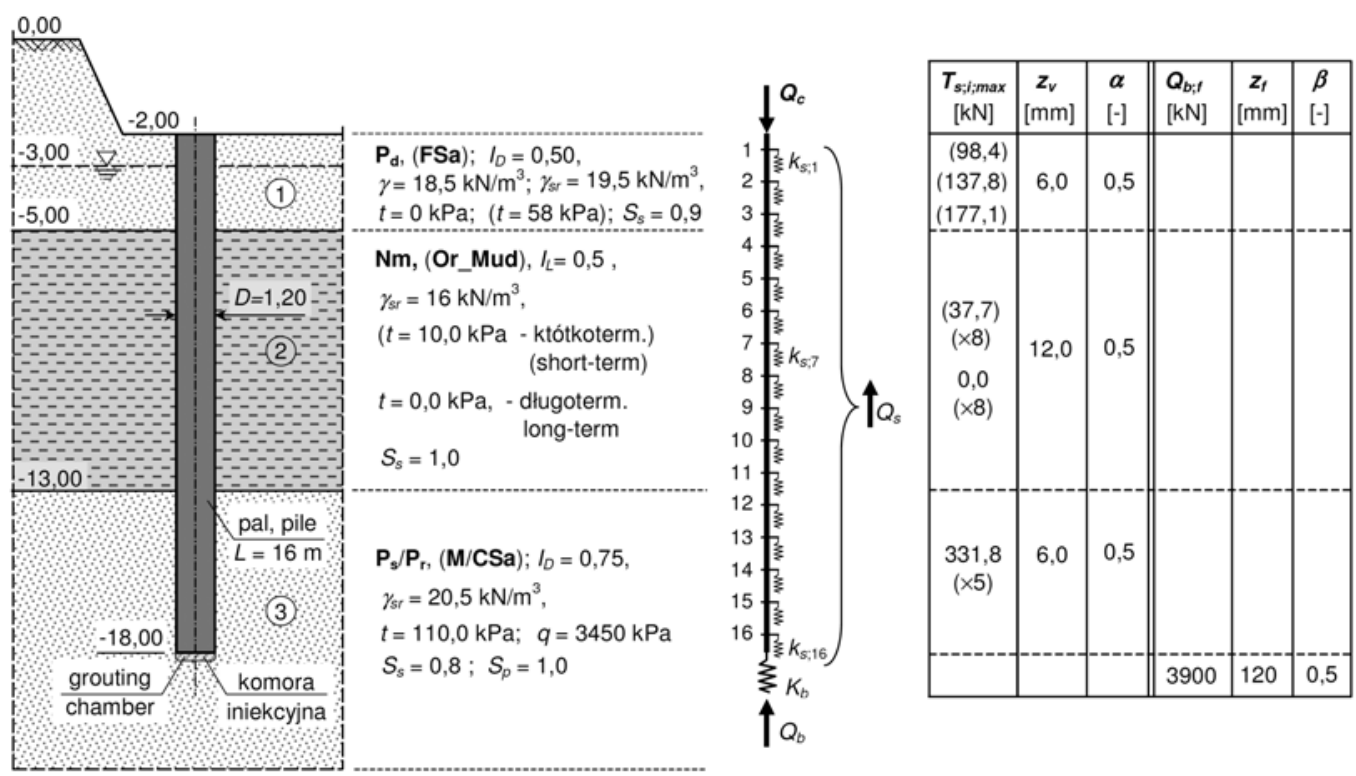

Rys. 12. Dane do przykładu obliczeniowego 2

Fig. 12. Data for the calculation of example 2 


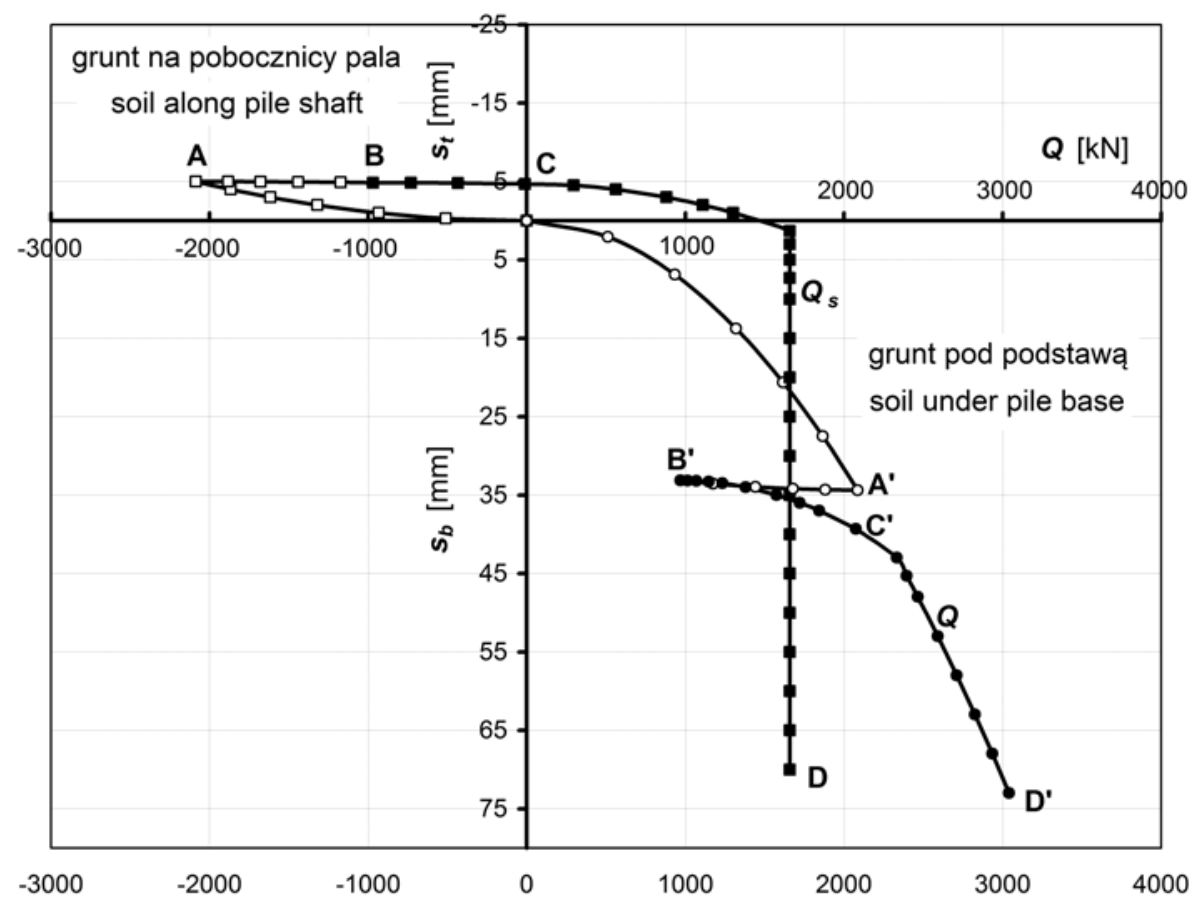

Rys. 13. Przykład 2 - wykresy oporów gruntu, otrzymane $z$ etapów obliczeniowych I do IV

Fig. 13. Calculation example 2 - soil resistance graphs obtained from the calculation phases I to IV

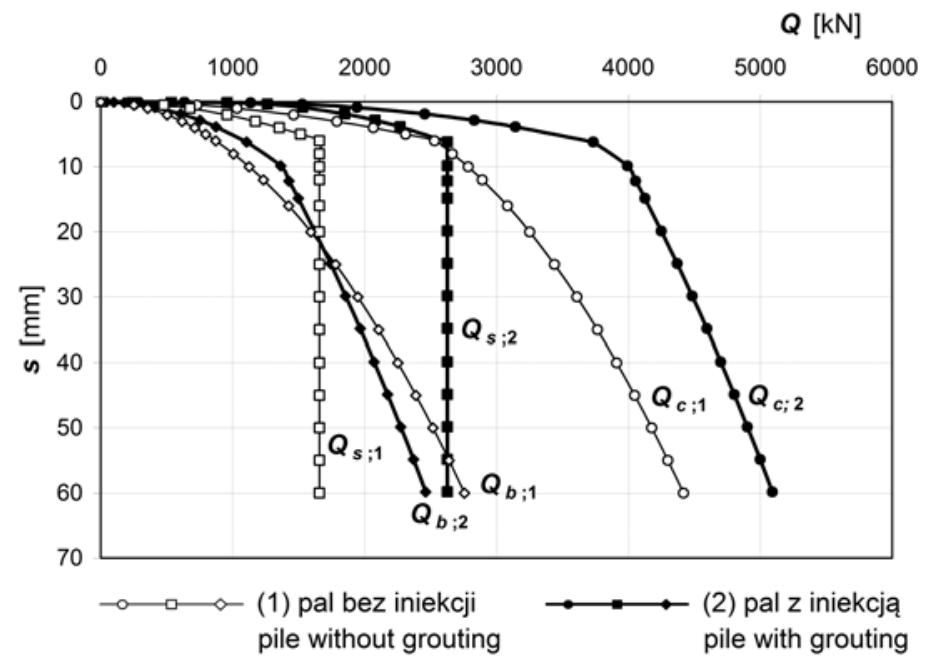

Rys. 14. Przykład 2 - porównanie krzywych osiadania pala bez iniekcji i pala z iniekcją podstawy

Fig. 14. Calculation example 2 - comparison of load-settlement characteristics for pile without grouting and pile with grouting under the base

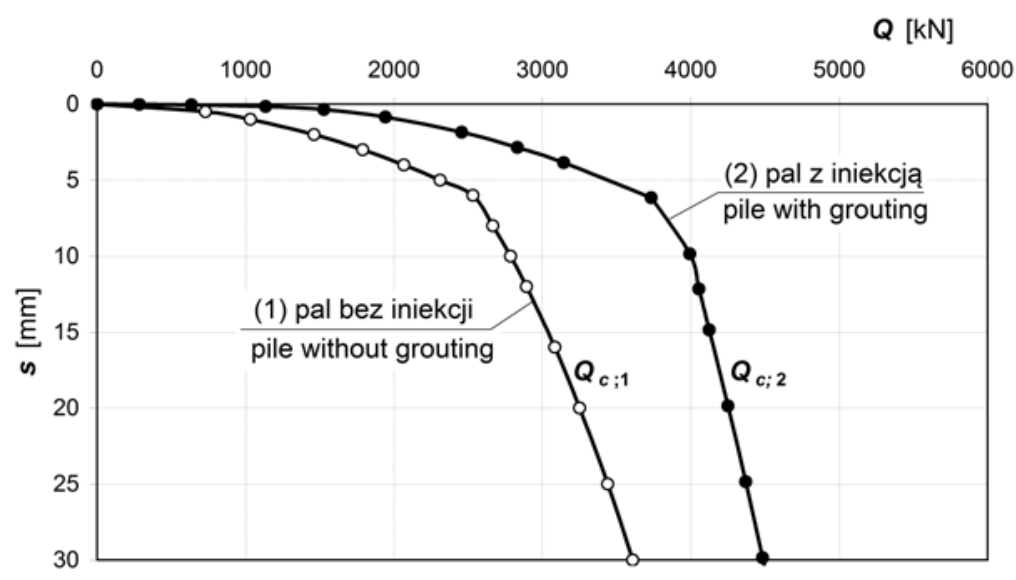

Rys. 15. Przykład 2 - powiększenie krzywych z rysunku 14 dla obciążeń całkowitych $\left(Q_{c}\right)$

Fig. 15. Calculation example 2 - enlarging of curves from Figure 14 for total loads $\left(Q_{c}\right)$ 
Można zauważyć podobny jak w przykładzie 1 efekt zastosowania iniekcji ciśnieniowej pod podstawą pala - zwiększenie się sztywności osiowej pala w zakresie obciążeń projektowych oraz przesunięcie do przodu punktu zagięcia na wykresie $Q-s$. Różnica w stosunku do wyników z przykładu 1 polega jednak na tym, że pal wykazuje mniejszą zdolność przenoszenia obciążeń zewnętrznych, co jest wynikiem obecności warstwy namułu, która została przyjęta jako nienośna. Spowodowało to obniżenie nośności zarówno pobocznicy, jak i podstawy pala.

\section{WNIOSKI}

Przedstawione $\mathrm{w}$ artykule rozważania i wyniki przykładowych obliczeń wykazały, że odpowiednio zastosowana i zmodyfikowana metoda funkcji transferowych może być dobrym oraz prostym narzędziem do prognozowania krzywej osiadania pala wierconego $\mathrm{z}$ iniekcją ciśnieniową pod podstawą.

Przy zastosowaniu zaproponowanej w artykule autorskiej procedury obliczeniowej uzyskuje się efekt działania iniekcji bardzo zbliżony do obserwowanego w rzeczywistości, polegający na zwiększeniu się sztywności osiowej pala w zakresie obciążeń projektowych, a nawet $\mathrm{w}$ obszarze przekraczającym ten zakres.

Przytoczone wyniki dwóch przykładów obliczeniowych wskazuja ponadto, że metoda i procedura obliczeniowa mogą być zastosowane do różnych warunków gruntowych. Przykład 2, z pośrednią warstwą namułu uznaną jako nienośna, pokazał dodatkowo, że pomimo takich samych wymiarów pala i takiego samego jego zagłębienia w identycznej warstwie nośnej co w przykładzie 1, iniekcja pod podstawą nie jest w stanie zapewnić charakterystyki $Q-S$ porównywalnej z charakterystyką pala z przykładu 1 . Iniekcja pod podstawą nie może być zatem traktowana jako sposób na zwiększenie nośności granicznej pala.

Zawarte przykłady obliczeniowe mają charakter czysto akademicki. Głównym ich celem, a także całego artykułu, było przedstawienie przebiegu oraz efektów działania procedury obliczeniowej. Jak każda nowa metoda obliczeniowa, również i ta zaprezentowana, mogąca mieć zastosowanie praktyczne, wymaga weryfikacji ilościowej z wynikami badań na obiektach rzeczywistych. Prace nad taką weryfikacją będą podjęte w najbliższej przyszłości, a jej wyniki będą przedmiotem kolejnych publikacji. Obecnie można zapewnić, że zarówno metoda funkcji transferowych, jak i przedstawiona autorska metoda dają oszacowania po bezpiecznej stronie.

Przy właściwym rozpoznaniu podłoża gruntowego i miarodajnym określeniu parametrów funkcji transferowych, zaprognozowana charakterystyka osiadania pala wierconego $\mathrm{z}$ iniekcją podstawy może być z powodzeniem wykorzystana do miarodajnego i efektywnego obliczania oraz projektowania fundamentów posadowionych na tego rodzaju palach. Efektywność takiego projektowania dodatkowo się zwiększy, gdy uzyskaną z obliczeń krzywą osiadania pala połączy się z koncepcją nowego (alternatywnego) podejścia do projektowania i obliczania fundamentów palowych, zaproponowaną i opublikowaną $\mathrm{w}$ pracach autora (Krasiński, 2015b; Gwizdała i Krasiński, 2016).

\section{PIŚMIENNICTWO}

Gwizdała, K. (1996). Analiza osiadań pali przy wykorzystaniu funkcji transformacyjnych. Zeszyty Naukowe Politechniki Gdańskiej, 532, Budownictwo Wodne 41, 1-190.

Gwizdała, K. (2011). Fundamenty palowe. Tom 1. Technologie $i$ obliczenia. Warszawa: PWN

Gwizdała, K. (2013). Fundamenty palowe. Tom 2. Badania $i$ zastosowania. Warszawa: PWN.

Gwizdała, K. i Pinkowski, A. (2007). Wpływ iniekcji pod podstawą na osiadanie pali wierconych w piaskach. Inżynieria i Budownictwo, 6(7-8), 379-381.

Gwizdała, K. i Krasiński, A. (2015). Zastosowanie pali wierconych wielkośrednicowych w fundamentowaniu obiektów mostowych. Mosty, 4, 24-29.

Gwizdała, K. i Krasiński, A. (2016). Fundamenty palowe, obliczenia z zastosowaniem zasad Eurokodu 7 i doświadczeń krajowych. Acta Scientiarum Polonorum Architectura, 15(2), 3-22.

Krasiński, A. (2015a). Ocena działania iniekcji pod podstawa pala wierconego za pomocą badania statycznego nośności z pomiarem rozkładu siły w trzonie pala. Inżynieria Morska i Geotechnika, 3, 461-464.

Krasiński, A. (2015b). Propozycja alternatywnego podejścia do obliczania i projektowania fundamentów palowych. Inżynieria Morska i Geotechnika, 5, 703-709.

Pinkowski, A. i Gwizdała, K. (2006). Analiza wpływu iniekcji pod podstawami pali wierconych. Zeszyty $\mathrm{Na}$ ukowe Politechniki Białostockiej. Budownictwo, 28(2), 213-222. 
Sobala, D. (2012). Projektowanie pali według Eurokodu 7 - metody i przykłady praktycznego wykorzystania. W Materiały Seminarium Podtoże i Fundamenty Budowli Drogowych, Autostrada Polska (strony 81-92). Kielce.

Sobala, D. (2014). Sposoby określania nośności geotechnicznej pali wciskanych - procedury i przykłady obliczeniowe według Eurokodu 7. Journal of Civil Engineering, Environment and Architecture, 31(61), 287-310.

PN-EN 1997-1:2008. Eurokod 7. Projektowanie geotechniczne. Część 1: Zasady ogólne.

PN-B-02482:1983. Fundamenty budowlane. Nośność pali i fundamentów palowych.

\title{
PREDICTION OF LOAD-SETTLEMENT CHARACTERISTIC OF BORED PILE WITH PRESSURE GROUTING UNDER THE BASE
}

\begin{abstract}
In the paper of 2015 by Krasiński the analysis and described the mechanism of pressure grouting action under the base of bored pile were presented. The considerations were supported by static load tests on instrumented bored piles of large diameter. The conclusion was that the grouting primarily activates and increases the pile shaft resistance and thanks to it improves the characteristics of bored pile interaction with soil. As a continuation of previous paper, the calculation method for prediction of load-settlement characteristic of bored pile with base grouting was proposed by the author in presented paper. In the calculation procedure the load transfer functions were applied and tested on two calculation examples. The computations, which can be carried out by using a spreadsheet like Excel give good results, which well reflect the real advantages of grounting under the base of bored pile.
\end{abstract}

Key words: pile, bored pile, grouting under the pile base, load-settlement characteristic of pile, calculation of piles 